\title{
Detection of Intravascular Coagulation
}

\author{
C. Thomas Kusker and Ruth Rush \\ From The Children's Hospital, The Children's Hospital Research Foundation, \\ and the Department of Pediatrics, University of Cincinnati, \\ Cincinnati, Ohio 45229
}

A B STRACT A method is described for the measurement of soluble thrombin-altered fibrinogen (circulating fibrin) in human plasma. This method is dependent upon the enzymatic incorporation of glycine ethyl ester${ }^{14} \mathrm{C}$ (GEE- ${ }^{14} \mathrm{C}$ ) into circulating fibrin by the action of the fibrin-stabilizing enzyme, factor XIII. The mean incorporation of $\mathrm{GEE}-{ }^{14} \mathrm{C}$ into the fibrinogen of normal human plasma controls was $167 \pm 47 \mathrm{dpm} / \mathrm{mg}$ fibrinogen. The addition of $0.03 \mathrm{NIH} \mathrm{U/ml} \mathrm{of} \mathrm{thrombin} \mathrm{to} \mathrm{normal}$ human plasma resulted in a two to threefold increase in the incorporation of $\mathrm{GEE}-{ }^{14} \mathrm{C}$ into the fibrinogen. The addition of plasmin split products of fibrinogen to normal plasma did not increase the incorporation of $\mathrm{GEE}-{ }^{14} \mathrm{C}$ unless these products were also exposed to thrombin. The addition of plasmin split products of a fibrin clot resulted in only minimal increase in the incorporation of GEE- ${ }^{14} \mathrm{C}$ ( $57 \mathrm{dpm} / \mathrm{mg}$ fibrinogen) at $37.5 \%$ concentration. The method was therefore sensitive to thrombin alterations of fibrinogen but insensitive to plasmin alterations of fibrinogen and fibrin.

Clinically, the method was found to provide useful information for the diagnosis and treatment of disseminated intravascular coagulation in two patients with meningococcemia, two patients with Rocky Mountain spotted fever, and three patients in whom therapeutic abortions were induced by the injection of hypertonic saline.

\section{INTRODUCTION}

The diagnosis and management of disseminated intravascular coagulation (DIC) ${ }^{1}$ are based on often inconsistent and confusing secondary changes in various

This work was presented at the 62nd Annual Meeting of the American Society for Clinical Investigation, May 1970.

Received for publication 8 June 1970 and in revised form 3 May 1971.

${ }^{1}$ Abbreviations used in this paper: DFP, diisopropylfluorophosphate; DIC, disseminated intravascular coagulation; GEE $-{ }^{14} \mathrm{C}$, glycine ethyl ester $-{ }^{14} \mathrm{C}$; SBTI, soybean trypsin inhibitor. clotting factors. Were it possible to measure soluble, thrombin-altered fibrinogen (circulating fibrin), the diagnosis and management of DIC could be based on the primary abnormality. For this purpose, a method for measuring circulating fibrin was designed which depends upon the enzymatic incorporation of glycine ethyl ester- ${ }^{14} \mathrm{C}\left(\mathrm{GEE}-{ }^{14} \mathrm{C}\right)$ into fibrin.

Lorand and Ong (1) incorporated $\mathrm{GEE}-{ }^{14} \mathrm{C}$ into purified fibrin with activated factor XIII, a fibrin-stabilizing enzyme. In the present studies, factor XIII and GEE- ${ }^{14} \mathrm{C}$ were added to an $8 \%$ ethanol fraction of human plasma and the amount of $\mathrm{GEE}-{ }^{14} \mathrm{C}$ incorporation in the clottable portion of this fraction measured. Applying this technique to in vitro and in vivo experiments revealed that an increase in incorporation occurred when thrombinaltered fibrinogen (circulating fibrin) was present, but no increase was detected when plasmin-digested fibrinogen (fibrinogen split products) were present unless the split products were also exposed to thrombin. The presence of plasmin-digested fibrin (fibrin split products) increased the incorporation only slightly at high concentrations.

\section{METHODS}

Preparation of plasma. $\mathrm{GEE}-{ }^{14} \mathrm{C}^{2}$ (3.04 $\left.\mathrm{mCi} / \mathrm{mmole}\right)$, crude streptokinase, ${ }^{3}$ and hirudin " were obtained commercially. The hirudin concentration was standardized according to the method of Rapaport (2). Blood for measurement of circulating fibrin was drawn by venepuncture into a plastic syringe and nine parts of blood were added to a conical $15 \mathrm{ml}$ polystyrene centrifuge tube ${ }^{5}$ containing one part of an anticoagulant mixture consisting of $2 \%$ EDTA, $10 \mathrm{U} / \mathrm{ml}$ hirudin, and $10 \mathrm{mg} / \mathrm{ml}$ soybean trypsin inhibitor (SBTI). The samples were centrifuged at $1800 \mathrm{~g}$ in an International centrifuge, ${ }^{6}$ model PR2, for $10 \mathrm{~min}$ and the supernatant platelet-poor plasma recovered. Assays were

\footnotetext{
${ }^{2}$ New England Nuclear Corp., Boston, Mass., lot No. 506-160.

3 "Varidase," Lederle Laboratories, Pearl River, N. Y.

"Sigma Chemical Co., St. Louis, Mo.

${ }^{5}$ Kimbel Products, Toledo, Ohio.

- International Equipment Co, Needham Heights, Mass.
} 
TABLE I

Factor XIII Activation

Mix in this order:

Factor XIII in $0.02 \mathrm{M}$ Tris, $0.15 \mathrm{M} \mathrm{NaCl}, \mathrm{pH} 7.4 \quad 0.3 \mathrm{ml}$

0.5 м cysteine, $0.1 \mathrm{M} \mathrm{CaCl}_{2}, 0.1$ м Tris, $0.75 \mathrm{M} \mathrm{NaCl}, \mathrm{pH} 7.4$

$0.05 \mathrm{ml}$

Thrombin $\left(100 \mathrm{NIH} \mathrm{U} / \mathrm{ml}\right.$ in $\left.0.01 \mathrm{M} \mathrm{CaCl}_{2}\right)$

$0.05 \mathrm{ml}$

Incubate $15 \mathrm{~min}$ at $37^{\circ} \mathrm{C}$ and then add:

$5 \times 10^{-4} \mathrm{M}$ diisopropylfluorophosphate

$0.05 \mathrm{ml}$

usually done the same day as the samples were obtained; however, samples could be frozen and stored for at least 2 wk at $-76^{\circ} \mathrm{C}$ without affecting results.

Factor XIII preparation, assay, and activation. Crude human factor XIII (fraction 5 in the method of Loewy and coworkers) was isolated as described by Loewy and coworkers (3) and its activity estimated according to their method at $800 \mathrm{U} / \mathrm{mg}$ protein. This crude fraction was used as enzyme for the incorporation of $\mathrm{GEE}-{ }^{14} \mathrm{C}$.

Human fibrinogen, ${ }^{7}$ deficient in factor XIII, was prepared by gradient elution chromatography of fibrinogen on diethylaminoethyl (DEAE) cellulose ${ }^{8}$ according to the method of Finlayson and Mosesson (4). The earliest protein eluted contained fibrinogen free of factor XIII activity when tested by allowing the fibrinogen to clot for $1 \mathrm{hr}$ in the presence of $2.5 \mathrm{NIH} \mathrm{U} / \mathrm{ml}$ thrombin, $0.005 \mathrm{M}$ cystine, $0.005 \mathrm{M}$ calcium, $0.075 \mathrm{M} \mathrm{KCL}$, and $0.5 \mathrm{mg} / \mathrm{ml}$ soybean trypsin inhibitor. This fibrinogen, once clotted, easily dissolved in $2 \%$ monochloracetic acid; the criterion for absent factor XIII activity.

Factor XIII was activated by incubating crude factor XIII in cysteine, calcium, and thrombin for $15 \mathrm{~min}$ at $37^{\circ} \mathrm{C}$ (see Table I). The thrombin activity was quenched at the end of the activation period by adding diisopropylfluorophosphate $^{8}$ (DFP), $5 \times 10^{-4} \mathrm{M}$. The active factor XIII mixture was diluted in $0.02 \mathrm{M}$ Tris, $0.15 \mathrm{M} \mathrm{NaCl}$ buffer, $0.05 \mathrm{M}$ cysteine, $0.01 \mathrm{M} \mathrm{CaCl}, \mathrm{pH} 7.4$, to a concentration of $30 \mathrm{U} / \mathrm{ml}$. This diluted activated factor XIII was used immediately in the reaction mixture for the labeling of circulating fibrin.

Labeling fibrin. An outline of the method for labeling the circulating fibrin in a plasma sample is presented in Table II. An $8 \%$ ethanol fraction of plasma was precipitated at $0^{\circ} \mathrm{C}$ for $1 \mathrm{hr}$ from $0.8 \mathrm{ml}$ of whole plasma with $0.2 \mathrm{ml} 40 \%$ ethanol in tris buffer, $\mathrm{pH} \mathrm{7.4}$. The ethanol precipitate was washed once with $2 \mathrm{ml} 8 \%$ ethanol at $0^{\circ} \mathrm{C}$ and dissolved in $0.8 \mathrm{ml}$ of tris buffer, $\mathrm{pH} 7.4 ; 1 \mathrm{mg} / \mathrm{ml}$ SBTI, $1 \mathrm{U} / \mathrm{ml}$ hirudin. After addition of $\mathrm{GEE}-{ }^{14} \mathrm{C}$, active factor XIII, and $0.25 \mathrm{~m}$ Tris, $0.05 \mathrm{M} \mathrm{NaCl}$ buffer, $\mathrm{pH} 8.2$, to the fibrinogen fraction, the mixture was incubated for 30 min at room temperature after which time $0.1 \mathrm{ml}$ of $0.25 \mathrm{M}$ EDTA was added to stop the action of factor XIII. The fibrinogen fraction was again precipitated from this mixture in $8 \%$ ethanol.

Recovery of clottable protein. The labeled $8 \%$ ethanol fraction was dissolved in $0.8 \mathrm{ml}$ of $0.04 \mathrm{M}$ Tris, $0.15 \mathrm{M}$ $\mathrm{NaCl} \mathrm{pH} \quad 7.4$ buffer containing $1 \mathrm{mg} / \mathrm{ml}$ SBTI, $0.2 \%$

\footnotetext{
${ }^{7}$ Merck, Sharp \& Dohme, West Point, Pa.

${ }^{8}$ Eastman Kodak Co, Rochester, N. Y.

- Mann Research Labs Inc., New York.
}

EDTA. The fibrinogen in the fraction was clotted by adding $0.1 \mathrm{ml}$ of bovine thrombin $(500 \mathrm{NIH} \mathrm{U} / \mathrm{ml})$ in $0.04 \mathrm{M}$ Tris, $0.15 \mathrm{M} \mathrm{NaCl}, 0.25 \mathrm{M}$ EDTA, $\mathrm{pH} 7.4$ to the fraction and the clottable protein harvested after $1 \mathrm{hr}$ of incubation with the thrombin at $37^{\circ} \mathrm{C}$ by removing the clot on a nicrome wire loop and drying it on filter paper. After dissolving the fibrin at $37^{\circ} \mathrm{C}$ in $3 \mathrm{ml}$ of $2 \%$ monochloracetic acid, the protein was reprecipitated with $3 \mathrm{ml}$ of $14 \%$ trichloracetic acid, washed four times with $7 \%$ trichloracetic acid to remove any unbound radioactivity, and redissolved in $3 \mathrm{ml}$ of $2 \%$ monochloracetic acid. The protein soluble in the $2 \%$ monochloracetic acid solution was quantitated by the method of Lowry (5) and then converted to milligrams of fibrinogen. The radioactive contents in $1 \mathrm{ml}$ of the monochloracetic acid solution were measured after its dilution in $10 \mathrm{ml}$ of liquid scintillation fluid (6) and results expressed as disintegrations per minute (dpm) per milligram of fibrinogen.

Standard coagulation studies. Plasma was recovered from blood collected in disposable syringes and mixed with $1 / 10$ vol of $0.1 \mathrm{M}$ buffered citrate anticoagulant $(0.1 \mathrm{M}$ sodium citrate, $0.1 \mathrm{M}$ citric acid, $\mathrm{pH} 5.0$ ) in polystyrene centrifuge tubes. The prothrombin time was performed using the method of Quick (7); activated partial thromboplastin times were measured by the method of Proctor and Rapaport (8) with activated platelet factor reagent. ${ }^{10}$ Fibrinogen concentration was determined by the method of Ratnoff and Menzie (9) and by the rapid heat precipitation method of Foster and coworkers (10). Factors V and VIII were quantitated by measuring the ability of the test plasma to correct the coagulation defect in plasma deficient in these factors $(11,12)$. The thrombin time was done as described by von Kaulla and von Kaulla (13) and the split products of fibrinogen in serum were detected on immunodiffusion of serum against antihuman fibrinogen ${ }^{11}$ as described by Merskey and coworkers (14) or by the use of the red cell hemaglutination inhibition assay (14). The ethanol gel test was done by the method of Breen and Tullis (15). Thrombin used in the experiments was bovine thrombin ${ }^{12}$ purified by chromatography on IRC-50 as described by Rasmussen (16). The specific activity of the purified preparation was $13,000 \mathrm{NIH} \mathrm{U/mg} \mathrm{protein.}$

\section{RESULTS}

Normal values. The mean values of amounts of GEE${ }^{14} \mathrm{C}$ incorporated into the $8 \%$ ethanol fraction of plasma

TABLE II

Reaction Mixture for Glycine Ethyl Ester (GEE) Labeling

Mix at room temperature:

$8 \%$ ethanol fraction

$0.8 \mathrm{ml}$

0.4 м GEE-14 $\mathrm{C}, 20 \mu \mathrm{Ci} / 0.1 \mathrm{ml}$

$0.1 \mathrm{ml}$

0.25 м Tris, $0.05 \mathrm{M} \mathrm{NaCl} p \mathrm{H} 8.2$

$0.1 \mathrm{ml}$

Activated fibrinase, $30 \mathrm{U} / \mathrm{ml}$

$0.1 \mathrm{ml}$

Incubate $30 \mathrm{~min}$ at room temperature, then add:

0.25 м Tris, 0.05 м NaCl, 0.25 м EDTA, pH $8.2 \quad 0.1 \mathrm{ml}$

${ }^{10}$ Baltimore Biological Laboratories, Baltimore, Md.

${ }^{11}$ Hyland Laboratories, Los Angeles, Calif.

${ }^{12}$ Parke, Davis \& Company, Detroit, Mich. 


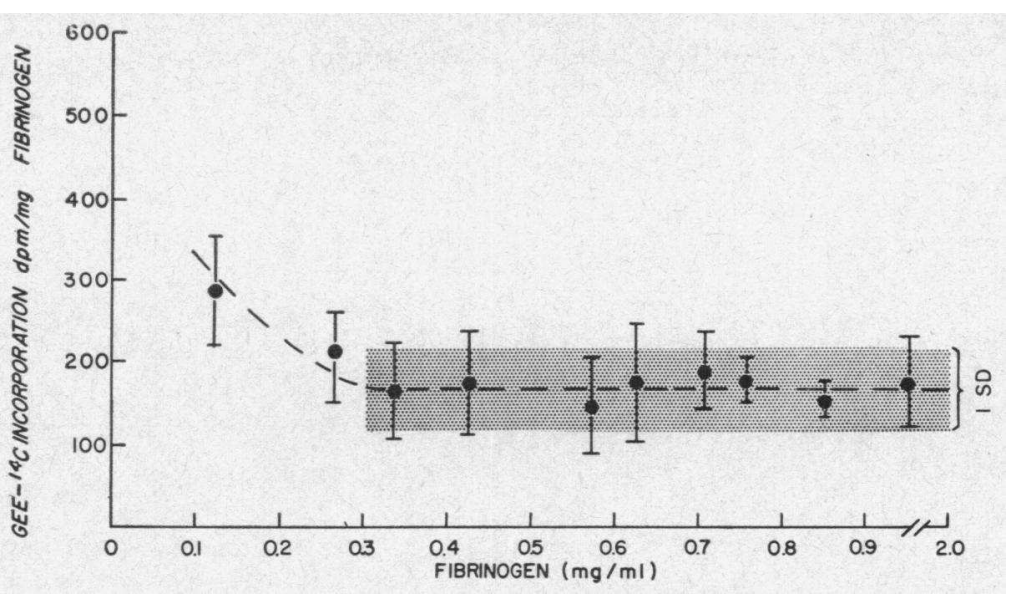

FIGURE 1 GEE- ${ }^{14} \mathrm{C}$ incorporation into normal human plasma fibrinogen (range of mean [vertical bars] and 1 SD $\mathrm{GEE}-{ }^{14} \mathrm{C}$ incorporation determined from six or more plasma samples).

samples from normal persons was $167 \pm 47 \mathrm{dpm} / \mathrm{mg}$ fibrinogen when the final fibrinogen concentration in the $2 \%$ monochloracetic acid was $0.3 \mathrm{mg} / \mathrm{ml}$ or greater. Fig. 1 describes the incorporation of $\mathrm{GEE}-{ }^{14} \mathrm{C}$ by 64 plasma samples from normal persons at various fibrinogen concentrations. Low and high levels of fibrinogen were achieved by increasing or decreasing the quantity of plasma precipitated with ethanol rather than by diluting plasma before precipitation. Each point in Fig. 1 represents the mean values of six or more normal human plasma samples and the bars represent one standard deviation of the mean. When the final fibrinogen concentration was $0.3 \mathrm{mg} / \mathrm{ml}$ or greater, the mean amount of GEE- ${ }^{14} \mathrm{C}$ incorporated was stable at $167 \pm 47 \mathrm{dpm} / \mathrm{mg}$ fibrinogen. If less than $0.3 \mathrm{mg} / \mathrm{ml}$ of fibrinogen was present, mean concentration of label was increased.

Thrombin-altered fibrinogen. The results of four in vitro studies in which soluble fibrin was formed by the addition of thrombin to plasma and changes in the incorporation of $\mathrm{GEE}-{ }^{14} \mathrm{C}$ determined are shown in Table III. To normal human plasma samples which already contained $0.2 \%$ EDTA and $1 \mathrm{mg} / \mathrm{ml} \mathrm{SBTI}$, purified bovine thrombin was added to give a final concentration of $0.03 \mathrm{NIH} \mathrm{U} / \mathrm{ml}$. The plasma thrombin mixtures were then incubated for $15 \mathrm{~min}$ at room temperature, and thrombin activity was then quenched by adding nine parts of plasma to one part hirudin $(10 \mathrm{U} / \mathrm{ml}$ in $0.02 \mathrm{M}$ Tris $0.15 \mathrm{M} \mathrm{NaCl} \mathrm{pH} 7.4$ buffer). Neither a visible clot nor fibrin strands appeared during incubation. In a similar experiment, hirudin $(1 \mathrm{U} / \mathrm{ml})$ was added to plasma before incubation with thrombin in order to block the enzymatic activity of thrombin on fibrinogen. After incubation of this mixture for $15 \mathrm{~min}$ at room temperature, there was no increase in the incorporation of GEE- ${ }^{14} \mathrm{C}$ (Table III). When a plasma (No. 2, No. 4) not previously exposed to thrombin was mixed with a sample of that same plasma which had been exposed to thrombin, the increase in incorporation of GEE- ${ }^{14} \mathrm{C}$ was proportional to the quantity of thrombin-treated plasma in the mixture (Table IV).

Urokinase-altered fibrinogen and fibrin. To exclude the possibility that fibrinogen or fibrin split products released by plasmin would significantly increase the incorporation of GEE- ${ }^{14} \mathrm{C}$ by plasma fibrinogen, plasma-containing fibrinogen and fibrin split products was tested for its capacity to incorporate $\mathrm{GEE}-{ }^{14} \mathrm{C}$. When normal human citrate plasma was incubated with urokinase $(500$ CTA U/ml final concentration) at $37^{\circ} \mathrm{C}$ for $18 \mathrm{hr}$, it was no longer clottable with thrombin. One-half of this plasma containing fibrinogen split products was then treated with thrombin (1 NIH U/ml final concentration) for $30 \mathrm{~min}$. Both plasmas (thrombin-treated and untreated) containing fibrinogen split products were then added, nine parts of the plasma to one part SBTI, EDTA, hirudin

TABLE III

GEE-14C Labeling of Thrombin-Treated Plasma

\begin{tabular}{lccc}
\hline & \multicolumn{2}{c}{ No thrombin } & Thrombin* \\
Plasma & $\begin{array}{c}\text { GEE-14C } \\
\text { labeling }\end{array}$ & $\begin{array}{l}\text { GEE-14C } \\
\text { labeling }\end{array}$ \\
\hline & \multicolumn{2}{c}{$d p m / m g$} & fibrinogen \\
1 & 181 & 381 \\
2 & 199 & 194 \\
3 & 165 & 474 \\
4 & 153 & 328 \\
& 124 & 482 \\
\hline
\end{tabular}

* Thrombin was added to a final concentration of $0.03 \mathrm{NIH}$ $\mathrm{U} / \mathrm{ml}$ for $15 \mathrm{~min}$ before adding hirudin.

Detection of Intravascular Coagulation 
TABLE IV

Mixtures of Thrombin-Treated and Untreated Plasma

\begin{tabular}{|c|c|c|c|c|}
\hline \multirow{3}{*}{$\begin{array}{l}\text { Per cent } \\
\text { thrombin- } \\
\text { treated } \\
\text { plasma }\end{array}$} & \multicolumn{4}{|c|}{ GEE-14C labeling } \\
\hline & \multicolumn{2}{|c|}{ Plasma No. 2} & \multicolumn{2}{|c|}{ Plasma No. 4} \\
\hline & Observed & Expected & Observed & Expected \\
\hline & \multicolumn{4}{|c|}{$d p m / m g$ fibrinogen } \\
\hline 0 & 165 & - & 124 & - \\
\hline 25 & 272 & 243 & 165 & 213 \\
\hline 50 & 319 & 322 & 242 & 300 \\
\hline 75 & 442 & 398 & 336 & 390 \\
\hline 100 & 474 & - & 482 & - \\
\hline
\end{tabular}

anticoagulant. Fibrin split products were prepared by incubating plasma with a final concentration of $10 \mathrm{NIH}$ $\mathrm{U} / \mathrm{ml}$ of thrombin for $15 \mathrm{~min}$ at $37^{\circ} \mathrm{C}$ to form a plasma clot. Urokinase was then added to the clot (final concentration of urokinase $500 \mathrm{CTA} \mathrm{U} / \mathrm{ml}$ ), and after clot lysis nine parts of this plasma were added to one part of standard EDTA, SBTI, hirudin anticoagulant.

The immunoelectrophoretic mobility of fibrinogen antigenic determinants in these plasmas was determined by immunoelectrophoresis on $2 \%$ agar (Fig. 2). In this Figure wells 1 and 2 contained normal plasma. The third well contained the plasma treated with urokinase and the fourth well contained the plasma clot treated with urokinase. After electrophoresis, immunofixation was done with rabbit antihuman fibrinogen antibody ${ }^{11}$ rendered monospecific by adsorption with human serum. Precipitin bands representing fibrinogen with altered mobility are seen in the urokinase-treated plasmas containing fibrinogen and fibrin split products. The untreated plasma samples (wells 1 and 2) contain single fibrinogen precipitin bands of identical net charge.

Plasma containing fibrinogen split products, which had not been exposed to thrombin, was mixed with nor-

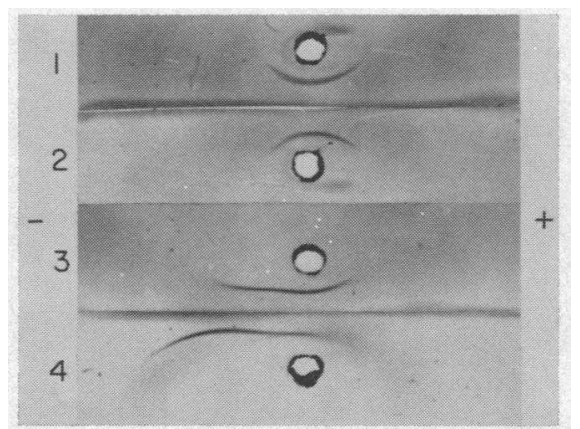

FIgURE 2 Agar electrophoresis with immunofixation against rabbit antihuman fibrinogen antibody. Well 1 , normal human plasma; well 2 , normal human plasma; well 3 , normal human plasma treated with $500 \mathrm{CTA} \mathrm{U} / \mathrm{ml}$ urokinase; well 4, normal human plasma clot treated with $500 \mathrm{CTA}$ $\mathrm{U} / \mathrm{ml}$ urokinase.

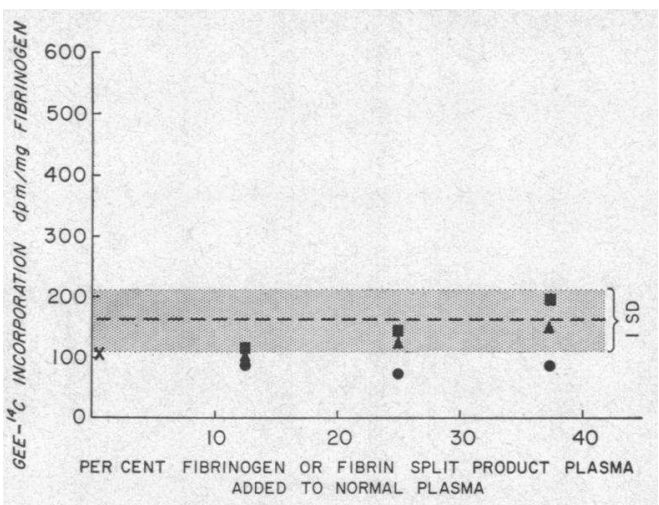

FIGURE 3 Mixtures of normal human plasma with plasma containing plasmin digestion products of fibrinogen and fibrin. $\times$, normal human plasma; $\bullet$, normal human plasma mixed with fibrinogen split products; $\mathbf{\square}$, normal human plasma mixed with thrombin-treated fibrinogen split products; $\boldsymbol{\Delta}$, normal human plasma mixed with fibrin split products.

mal human plasma. The incorporation of $\mathrm{GEE}-{ }^{14} \mathrm{C}$ into the fibrinogen in these mixtures was no greater than that in normal plasma alone (Fig. 3). However, the mixture of normal plasma with $37.5 \%$ fibrinogen split products that had also been exposed to thrombin incorporated more $\mathrm{GEE}-{ }^{14} \mathrm{C}(108 \mathrm{dpm} / \mathrm{mg}$ fibrinogen above the normal plasma alone). The GEE- ${ }^{14} \mathrm{C}$ incorporation into the fibrinogen of normal plasma with $37.5 \%$ fibrin split products increased only $57 \mathrm{dpm} / \mathrm{mg}$ fibrinogen above the normal plasma. Therefore, plasmin-digested fibrinogen increased the incorporation of $\mathrm{GEE}-{ }^{14} \mathrm{C}$ in normal plasma only after being hydrolyzed by thrombin, and plasmin-digested fibrin clot in normal plasma increased GEE- $-{ }^{14} \mathrm{C}$ incorporation only minimally and only at high concentrations.

Per cent recovery. As the concentration of fibrinogen or fibrin split products added to normal plasma was increased, the amount of clottable protein which could be recovered from the mixtures decreased. When the concentration of fibrin split products was increased to 37.5 , the per cent of fibrinogen recovered was only $18 \%$ of that expected. With concentrations greater than $37.5 \%$, the $8 \%$ ethanol fraction was no longer clottable and recovery was therefore zero. However, provided the over-all recovery was $0.3 \mathrm{mg} / \mathrm{ml}$ of protein in the final 3 cc of $2 \%$ monochloracetic acid solution, variation in the recovery of fibrinogen from plasma was not related to changes in incorporation of GEE- ${ }^{14} \mathrm{C}$.

Dogs infused with thrombin. To evaluate the method for measuring circulating fibrin in vivo, two mongrel dogs were anesthetized with Penthrane ${ }^{11}$ and the saphenous veins of the hind limb and fore limb were cannulated with No. 19 scalp vein sets. Blood samples were withdrawn from the saphenous vein of the fore limb at 
varying time intervals before, during, and after continuous intravenous infusion of bovine thrombin into the hind limb. In one experiment factors V and VIII were measured on the samples using plasma from humans severely congenitally deficient in each factor as substrate for determining the ability of the dog plasma to shorten their clotting times $(11,12)$. Fibrinogen concentrations were determined by the method of Ratnoff and Menzie (9) and serum was tested for split products of fibrinogen by immunodiffusion (14). When given an infusion of $1 \mathrm{NIH} \mathrm{U} / \mathrm{kg}$ per min of bovine thrombin for $20 \mathrm{~min}$, an early increase in the ability of the plasma from two dogs to incorporate $\mathrm{GEE}-{ }^{14} \mathrm{C}$ into fibrinogen occurred and persisted for $1 \mathrm{hr}$ after cessation of the infusion (Fig. 4). Concentrations of factors V, VIII, and fibrinogen in the plasma of dog No. 4 decreased and split products were present toward the end of the 20 min thrombin infusion (Table V).

Clinical observations. Two patients with bacteriologically proven meningococcemia were found to have circulating fibrin in association with other evidence suggesting disseminated intravascular coagulation (DIC). The first, patient $\mathrm{A}$, was a $34 / 12$ yr old girl admitted to the hospital with a temperature of $104^{\circ} \mathrm{F}$, blood pressure $86 / 50$, and a generalized petechial rash. The prothrombin time of her plasma was prolonged (15 sec; normal, $12 \mathrm{sec})$, but the partial thromboplastin time was normal $(37 \mathrm{sec})$, as was the fibrinogen concentration measured by the heat precipitation method $(190 \mathrm{mg} / 100$ $\mathrm{ml}$ ), and the number of platelets appeared normal on the blood smear. The ethanol gel test was negative. Circulating fibrin, however, was present, as indicated by a GEE- ${ }^{14} \mathrm{C}$ incorporation of $344 \mathrm{dpm} / \mathrm{mg}$ fibrinogen. 11 $\mathrm{hr}$ after the initiation of heparin therapy the level of GEE ${ }^{14} \mathrm{C}$ incorporation had returned to normal, $188 \mathrm{dpm} /$

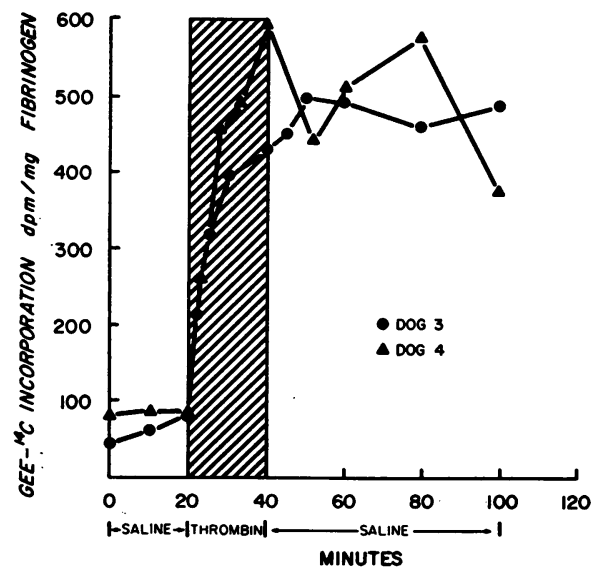

FIGURE 4 Dogs given intravenous thrombin, $1 \mathrm{U} / \mathrm{kg}$ per min for $20 \mathrm{~min}$. Venous blood samples withdrawn at timed intervals before, during, and after infusion and $\mathrm{GEE}-{ }^{14} \mathrm{C}$ incorporation measured.
TABLE V

Infusion with Thrombin, $1 \mathrm{U} / \mathrm{kg}$ per min, Dog 4

\begin{tabular}{rlclcc}
\hline Time & Infusion & Fibrinogen & $\begin{array}{c}\text { Split } \\
\text { products }\end{array}$ & $\begin{array}{c}\text { Factor } \\
\text { V }\end{array}$ & $\begin{array}{c}\text { Factor } \\
\text { VIII }\end{array}$ \\
\hline min & & $m g / 100 m l$ & & $\%$ & $\%$ \\
0 & saline & 664 & Negative & 100 & 100 \\
10 & saline & 702 & Negative & 100 & 88.5 \\
20 & saline & 680 & Negative & 100 & 154 \\
23 & thrombin & 578 & Negative & 80 & - \\
28 & thrombin & 279 & Negative & 86 & 59 \\
33 & thrombin & 455 & Negative & 86 & 46 \\
40 & thrombin & 325 & Positive & 85 & 32 \\
50 & saline & 222 & Positive & 60 & 48 \\
70 & saline & 358 & Positive & 53 & 49 \\
90 & saline & 433 & Positive & 56 & 53 \\
110 & saline & 452 & Positive & 54 & 48 \\
\hline
\end{tabular}

mg fibrinogen. Heparin was discontinued and the patient recovered.

The second patient with meningococcemia, a 7 month old girl, was admitted to the hospital in a moribund condition with a temperautre of $102^{\circ} \mathrm{C}$; blood pressure, $80 / 40$; generalized petechiae and ecchymoses. She had received $250 \mathrm{U}$ of heparin at another hospital before her admission to The Children's Hospital. Her fibrinogen $\mathrm{GEE}-{ }^{14} \mathrm{C}$ incorporation was increased, $585 \mathrm{dpm} / \mathrm{mg}$ fibrinogen, and the ethanol gel test was positive. Heparin treatment was continued and $12 \mathrm{hr}$ after admission GEE${ }^{14} \mathrm{C}$ incorporation had returned to normal, $129 \mathrm{dpm} / \mathrm{mg}$ fibrinogen. However, the patient had a cardiac arrest and died $16 \mathrm{hr}$ after admission.

Two patients with Rocky Mountain spotted fever were studied. Plasma from both had prolonged prothrombin times (27.6 sec and $22.9 \mathrm{sec}$ ), prolonged partial thromboplastin times ( $70 \mathrm{sec}$ and $67.2 \mathrm{sec}$ ), less than $50 \mathrm{mg} /$ $100 \mathrm{ml}$ of fibrinogen by the heat precipitation method and low platelet counts $\left(7,900\right.$ and $\left.12,000 / \mathrm{mm}^{3}\right)$. Neither patient had a positive ethanol gel test. In plasma from both patients, increased amounts of $\mathrm{GEE}-{ }^{14} \mathrm{C}$ were incorporated (499.2 and $358.7 \mathrm{dpm} / \mathrm{mg}$ fibrinogen). Both patients recovered after therapy with antibiotics and heparin, and when $\mathrm{GEE}-{ }^{14} \mathrm{C}$ incorporation was repeated $24 \mathrm{hr}$ and $1 \mathrm{wk}$ after admission, the amounts were within the normal range (222 and $129 \mathrm{dpm} / \mathrm{mg}$ fibrinogen).

Three patients, E, F, and G, were studied in whom therapeutic abortions were induced by the intrauterine injection of hypertonic saline. Details of these patients have been presented in a separate publication (17). All three patients developed circulating fibrin after the intrauterine injection of saline as measured by GEE- ${ }^{14} \mathrm{C}$ incorporation. One patient $(\mathrm{E})$ with a retained dead fetus had increased $\mathrm{GEE}-{ }^{14} \mathrm{C}$ incorporation before the injection of hypertonic saline. All three patients had 
TABLE VI

Saline-Induced Abortion

\begin{tabular}{|c|c|c|c|c|c|c|c|}
\hline Patient & Time & $\begin{array}{c}\text { GEE-14C } \\
\text { incorporation }\end{array}$ & Factor V & Factor VIII & Fibrinogen* & $\begin{array}{l}\text { Ethanol } \\
\text { gel test }\end{array}$ & $\begin{array}{l}\text { Fibrin split } \\
\text { products }\end{array}$ \\
\hline & & $\begin{array}{c}d p m / m g \\
\text { fibrinogen }\end{array}$ & $\%$ & $\%$ & $m g / m l$ & & \\
\hline \multirow[t]{4}{*}{$\mathrm{E}$} & Preinjection & 289 & 78 & 110 & 391 & Negative & $2.9 \mathrm{ug} / \mathrm{ml} \ddagger$ \\
\hline & $2 \mathrm{hr}$ postinjection & 400 & 100 & 93 & 280 & Negative & $36.0 \mathrm{ug} / \mathrm{ml} \ddagger$ \\
\hline & $6 \mathrm{hr}$ postinjection & 551 & 40 & 40 & 280 & Negative & $72.5 \mathrm{ug} / \mathrm{ml}$ \\
\hline & $35 \mathrm{hr}$ postinjection & 232 & 86 & 102 & 260 & Negative & $72.5 \mathrm{ug} / \mathrm{ml}$ \\
\hline \multirow[t]{4}{*}{$\mathrm{F}$} & Preinjection & 237 & 107 & 165 & 280 & Negative & Negative§ \\
\hline & $3 \mathrm{hr}$ postinjection & 469 & 96 & 96 & 190 & Negative & Negative§ \\
\hline & $9.5 \mathrm{hr}$ postinjection & 808 & 93 & 52 & 150 & Negative & Negative $\S$ \\
\hline & $50 \mathrm{hr}$ postinjection & 233 & 234 & 182 & 280 & Negative & Positive $1: 8 \S$ \\
\hline \multirow[t]{4}{*}{ G } & Preinjection & 227 & 63 & 109 & 230 & Negative & Not done \\
\hline & $2 \mathrm{hr}$ postinjection & 427 & 73 & 108 & 190 & Negative & Not done \\
\hline & $6 \mathrm{hr}$ postinjection & 494 & 36 & 78 & 150 & Negative & Not done \\
\hline & $74 \mathrm{hr}$ postinjection & 196 & 78 & 175 & 210 & Negative & Not done \\
\hline
\end{tabular}

* Method of Ratnoff and Menzie.

$\ddagger$ Mersky red cell hemaglutination inhibition assay.

$\S$ Fi test, Hyland Laboratories fibrin split products assay.

changes in other coagulation factors consistent with the diagnosis of disseminated intravascular coagulation ( $\mathrm{Ta}$ ble VI).

Patients with other acute illnesses have also been studied, but did not have circulating fibrin as measured by GEE- ${ }^{14} \mathrm{C}$ incorporation. Included in this group were two patients with prosthetic heart valves and thrombocytopenia, a patient with bacteriologically proven meningococcal meningitis without septicemia, and three patients with the hemolytic-uremic syndrome.

\section{DISCUSSION}

Diminished concentrations of clotting factors known to be consumed during clotting plus evidence of fibrinolytic activity may permit a presumptive diagnosis of intravascular clotting. Increased consumption of a clotting factor may be inapparent, however, when the rate of synthesis or degree of activation of a clotting factor exceeds its rate of consumption. The present study was designed to evaluate a method for direct measurement of an effect of thrombin by measuring that portion of fibrinogen in plasma which has been converted to fibrin but remained soluble (circulating fibrin). Lorand and Ong (1) originally demonstrated the enzymatic incorporation of GEE${ }^{14} \mathrm{C}$ into fibrin. The method described in this manuscript is based upon theirs in which GEE- ${ }^{14} \mathrm{C}$ is incorporated into fibrin by the action of factor XIII.

In the method described, EDTA, hirudin, and SBTI were added to the plasma and the $8 \%$ ethanol fraction before and during the enzymatic incorporation of GEE${ }^{14} \mathrm{C}$ into fibrinogen to prevent any further proteolytic alterations of the fibrinogen once it had been removed from the patient. Since only the clottable portion of the $8 \%$ ethanol fraction of plasma was tested for incorporation of $\mathrm{GEE}-{ }^{14} \mathrm{C}$, it is not known whether other nonclottable proteins in this fraction may also incorporate the label. Under the conditions described, some incorporation occurred in the clottable protein portion of the $8 \%$ ethanol fraction in normal plasma $(167 \pm 47 \mathrm{dpm} / \mathrm{mg}$ fibrinogen), as if there may be circulating fibrin in normal plasma. However, these studies do not exclude the possible incorporation of some $\mathrm{GEE}-{ }^{14} \mathrm{C}$ by unaltered fibrinogen. When the amount of normal plasma was decreased so that the final yield of fibrinogen was less than $0.3 \mathrm{mg} / \mathrm{ml}(0.9 \mathrm{mg}$ total $)$, there was a progressive increase in the incorporation of the label. This finding suggests that increased incorporation of GEE- ${ }^{14} \mathrm{C}$ in unaltered fibrinogen will occur at high enzyme to substrate concentrations. If the final yield of fibrinogen was 0.3 $\mathrm{mg} / \mathrm{ml}$ or greater, no significant variation in labeling. was found even though the over-all recovery of fibrinogen was only $18 \%$. Though some incorporation may occur with unaltered fibrinogen, the presence of thrombinaltered fibrinogen (circulating fibrin) markedly increased the incorporation of $\mathrm{GEE}-{ }^{14} \mathrm{C}$. This effect was clearly evident when thrombin was added to normal plasma in vitro (Tables III and IV) and in animal studies in which dogs were given continuous intravenous infusions of thrombin (Fig. 4).

The ethanol gel test of Breen and Tullis (15) proposed as a specific measure for the presence of circulating fibrin was apparently not reliable in that it was often 
negative in the face of evidence that circulating fibrin was present as measured by $\mathrm{GEE}-{ }^{14} \mathrm{C}$ incorporation. Moreover, plasma from the two patients with Rocky Mountain spotted fever and all three women after induced abortion had alterations of other clotting factors, including $\mathrm{GEE}-{ }^{14} \mathrm{C}$ incorporation, consistent with the diagnosis of disseminated intravascular coagulation although the ethanol gel test was negative in all instances.

The possibility that plasmin-altered fibrinogen or fibrin night increase $\mathrm{GEE}-{ }^{14} \mathrm{C}$ incorporation was considered. Urokinase-induced split products of unclotted fibrinogen did not significantly increase the incorporation of the label when mixed with normal plasma unless these products were exposed to thrombin. Urokinase-induced split products from a fibrin clot when present at $37.5 \%$ concentration in normal plasma increased the labeling by only $57 \mathrm{dpm} / \mathrm{mg}$ fibrinogen. The appearance of split products in the serum of the dog infused with thrombin and in patients with DIC did not correlate with changes in GEE- $-{ }^{14} \mathrm{C}$ incorporation. Thus the method is apparently insensitive to plasmin alterations of fibrinogen and fibrin.

The potential usefulness of the method for measuring circulating fibrin was shown in the patients studied. The first patient with meningococcemia had circulating fibrin as measured by $\mathrm{GEE}-{ }^{14} \mathrm{C}$. With heparin therapy, the $\mathrm{GEE}-{ }^{14} \mathrm{C}$ labeling of fibrinogen returned to normal, suggesting that the patient suffered an episode of disseminated intravascular coagulation which improved on therapy with heparin. Other changes in clotting factor concentrations suggestive of disseminated intravascular coagulation were not, however, present in this patient. The three patients in whom intrauterine injection of hypertonic saline was used for the induction of therapeutic abortion all had circulating fibrin as measured by GEE- ${ }^{14} \mathrm{C}$ incorporation. The usual changes in coagulation factor concentrations associated with disseminated intravascular coagulation also occurred in these patients (Table VI). The diagnosis of disseminated intravascular coagulation could therefore have ultimately been made by conventional methods, although increased $\mathrm{GEE}-{ }^{14} \mathrm{C}$ incorporation preceded other changes. The method thus provides a sensitive tool for identifying circulating fibrin in DIC and should therefore aid in our understanding of this condition and its therapy.

\section{REFERENCES}

1. Lorand, L., and H. H. Ong. 1966. Labeling of amineacceptor cross-linking sites of fibrin by transpeptidation. Biochemistry. 5: 1747.
2. Rapaport, S. I., P. F. Hjort, and M. J. Patch. 1965. Further evidence that thrombin-activation of factor VIII is an essential step in intrinsic clotting. Scand. J. Clin. Lab. Invest. 17 (Suppl. 84) : 88.

3. Loewy, A. G., K. Dunathan, R. Kriel, and H. L. Wolfinger, Jr. 1961. Fibrinase. I. Purification of substrate and enzyme. J. Biol. ( hcm. 236: 2625.

4. Finlayson, J. S., and M. W. Mosesson. 1963. Heterogeneity of human fibrinogen. Biochemistry. 2: 42.

5. Lowry, O. H., N. J. Rosebrough, A. L. Farr, and R. J. Randall. 1951. Protein measurement with the folin phenol reagent. J. Biol. Chem. 193: 265.

6. Tye, R., and J. D. Engel. 1965. Liquid scintillation counting of carbon-14 in aqueous digests of whole tissues. Anal. Chem. 37: 1225 .

7. Tocantins, L. M. 1964. Estimation of prothrombin (onestage method of Quick). In Blood Coagulation, Hemorrhage and Thrombosis; Methods of Study. L. M. Tocantins and L. A. Kazal, editors. Grune \& Stratton, Inc., New York. 2nd edition. 148.

8. Proctor, R. R., and S. I. Rapaport. 1961. The partial thromboplastin time with kaolin: a simple screening test for first stage plasma clotting factor deficiencies. Amer. J. Clin. Pathol. 36: 212.

9. Ratnoff, O. D., and C. Menzie. 1951. A new method for the determination of fibrinogen in small samples of plasma. J. Lab. Clin. Med. 37: 316.

10. Foster. J. B. T., A. DeNatale, and L. B. Dotti. 1959. Determination of plasma fibrinogen by means of centrifugation after heating. Amer. J. Clin. Pathol. 31: 42.

11. Langdell, R. D., R. H. Wagner, and K. M. Brinkhous. 1964. Determination of the partial thromboplastin time (PTT). In Blood Coagulation, Hemorrhage and Thrombosis. L. M. Tocantins and L. A. Kazal, editors. Grune \& Stratton, Inc, New York. 2nd edition. 103.

12. Carroll, R. T. 1964. Estimation of accelerator globulin (one-stage method of Lewis and Ware). In Blood Coagulation, Hemorrhage and Thrombosis. L. M. Tocantins and L. A. Kazal, editors. Grune \& Stratton, Inc., New York. 2nd edition. 194.

13. von Kaulla, K. N., and E. von Kaulla. Estimation of the thrombin time of plasma. In Blood Coagulation, Hemorrhage and Thrombosis. L. M. Tocantins and L. A. Kazal, editors. Grune \& Stratton, Inc., New York. 2nd edition. 335

14. Merskey, C., A. J. Johnson, J. H. Pert, and H. Wohl. 1964. Pathogenesis of fibrinolysis in defibrination syndrome: effect of heparin administration. Blood. 24: 701.

15. Breen, F. A., Jr., and J. L. Tullis. 1968. Ethanol gelation: a rapid screening test for intravascular coagulation. Ann. Intern. Med. 69: 1197.

16. Rasmussen, P. S. 1955. Purification of thrombin by chromatography. Biochim. Biophys. Acta. 16: 157.

17. Stander, R. W., H. C. Flessa, H. I. Glueck, and C. T. Kisker. 1970. Alteration of maternal coagulation factors following intraamniotic injection of hypertonic saline. Obstet. Gynecol. $37: 660$. 